
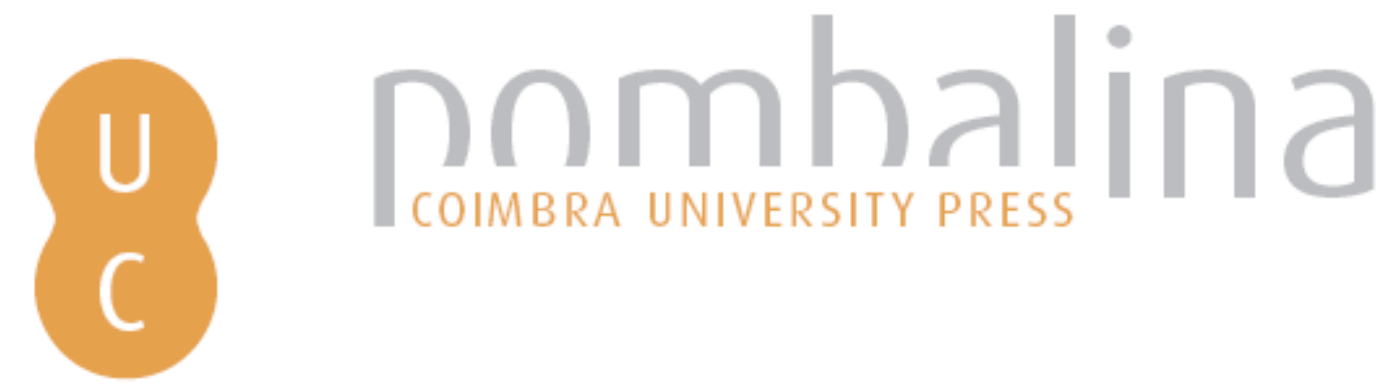

\title{
The Cult of Isis in Rome: some aspects of its Reception and the Testimony of Apuleius' Asinus Aureus
}

\author{
Autor(es): $\quad$ Teixeira, Cláudia \\ Edições Afrontamento; CITCEM - Centro de Investigação \\ Publicado por: Transdisciplinar «Cultura, Espaço e Memória»; Centro de Estudos \\ Clássicos e Humanísticos; Alexandria University; Imprensa da \\ Universidade de Coimbra \\ URL \\ persistente: \\ URI:http://hdl.handle.net/10316.2/36185 \\ DOI: \\ DOI:http://dx.doi.org/10.14195/978-989-26-0966-9_19 \\ Accessed : $\quad$ 26-Apr-2023 12:03:53
}

A navegação consulta e descarregamento dos títulos inseridos nas Bibliotecas Digitais UC Digitalis, UC Pombalina e UC Impactum, pressupõem a aceitação plena e sem reservas dos Termos e Condições de Uso destas Bibliotecas Digitais, disponíveis em https://digitalis.uc.pt/pt-pt/termos.

Conforme exposto nos referidos Termos e Condições de Uso, o descarregamento de títulos de acesso restrito requer uma licença válida de autorização devendo o utilizador aceder ao(s) documento(s) a partir de um endereço de IP da instituição detentora da supramencionada licença.

Ao utilizador é apenas permitido o descarregamento para uso pessoal, pelo que o emprego do(s) título(s) descarregado(s) para outro fim, designadamente comercial, carece de autorização do respetivo autor ou editor da obra.

Na medida em que todas as obras da UC Digitalis se encontram protegidas pelo Código do Direito de Autor e Direitos Conexos e demais legislação aplicável, toda a cópia, parcial ou total, deste documento, nos casos em que é legalmente admitida, deverá conter ou fazer-se acompanhar por este aviso.

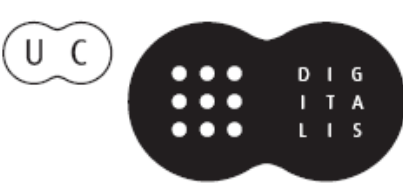




\title{
THE CULT OF ISIS IN ROME: SOME ASPECTS OF ITS RECEPTION AND THE TESTIMONY OF APULEIUS' ASINVS AVREVS
}

\section{CLÁUDIA TEIXEIRA}

University of Évora. Centro de Estudos Clássicos e Humanísticos (University of Coimbra). Centro de História (University of Lisbon).

\begin{abstract}
After providing a brief summary of the most significant aspects of the reception of the cult of Isis in Rome and of its relationship with political power, this chapter focuses on Apuleius' Asinus Aureus in order to analyze some aspects of the Isiac cult that may have justified its success among Romans: its universal character, its connection to justice, and its capacity to produce direct communication between individual goddess and religious institutions.
\end{abstract}

The cult of Isis seems to be, as a whole, one of the best examples of the connection between political aspects of religion and the lives of the individuals taking part in it. Its difficult reception in the Roman world, particularly during the first centuries of its implementation, can be seen as a typical case of action-reaction (action on the part of its coreligionists, initially restricted to the lower social classes; reaction by political institutions, which either allowed for the cult's existence, or created limitations and prohibitions in accordance with the political interests that marked different periods). On the other hand, the growing popularity of the cult derived overall from the nature of the divinity and from its communicative potential. For the Egyptians, Isis was the goddess of life, protector and mother of Pharaohs, the protagonist in the story of Osiris' resurrection, the mother of Horus and goddess of a thousand names. Isis embodied therefore a multitude of divine attributes and abilities ${ }^{1}$. On

\footnotetext{
${ }^{1}$ LÓPES SALVÁ, 1992: 163: «Isis (...) era una diosa universal (...) por su capacidad de adaptación a todas las circunstancias, y que además prestaba atención individualizada a sus devotos concediéndoles salud y bienestar».
} 
the other hand, the myth related to the goddess was rooted on a divine narrative of suffering and triumph over adversity, thus increasing people's ability to identify with the goddess. On the whole, Isis and her narrative represent a matrix that is simultaneously divine and human, protective and magnanimous, and capable of a kind of justice that is as intelligible as it is universal, and therefore very difficult to associate with any other deity worshipped among Greeks and Romans.

Nevertheless, before achieving such definition, this goddess and her cult underwent a process of evolution in and around the city of Alexandria, which became a locus for the cult's development and promoted its cultural reception within the Greco-Roman context. Isis' first appearance in the Greek space, however, took place at an earlier stage and is indebted to the deep tradition of exchanges between the Greek and Egyptian material cultures. Archaeology attests explicit references to the goddess Isis the Archaic and Classical periods ${ }^{2}$. During the 2 nd and 1st centuries B.C. the cult was already present, according to archaeological information, in most Greek cities ${ }^{3}$. However, the cult of Isis that spread in Greece and resulted from the hellenization of the cult that took place in Alexandria

The renewal of the goddess in the Alexandrian context ${ }^{4}$ was traditionally justified by a political necessity of Ptolemy I (305-282 B.C.) to find an element of religious homogeneity that would unify the two distinct populations living in Egypt by creating a common identity. In this way, Alexandria would have witnessed, in this period, the birth of Sarapis, a Hellenized version of Osiris, whose association with Isis would appeal to both Egyptians and Greeks, thus becoming inseparable divinities in the Greco-Roman world, as the epigraphic evidence shows. Today, this thesis of the Ptolemaic creation of Sarapis and the political motives underlying the promotion and the propagation of the cult outside of Egypt is rejected by many scholars ${ }^{5}$ in favour of a perspective which supports the notion of a spontaneous expansion, promoted by merchants and travellers, by Greeks who served in the Egyptian army and also by slaves 6 . This new way of thinking, however, does not hinder the idea

\footnotetext{
${ }^{2}$ For the Hellenization of the cult of Isis, vide NAOUM, 2008.

${ }^{3}$ Vide HEYBOB, 1975, especially the references to the inscriptions, pages 7-9.

${ }^{4}$ Among others, see the discussion of the problem in HEYBOB, 1975: 2-6; LÉVÊQUE, 1987: 153; LÓPES SALVÁ, 1992: 164-165.

${ }^{5}$ ALVAR (2008) observes: «There were a number of quite different versions of Sarapis’ origins. Few nowadays credit the story that the friends of Alexander had consulted the god in his temple in Babylonia when the King was dying. It has been suggested that this was some kind of oracular Baal subsequently identified with Sarapis. By this account, Serapis might have been taken to Sinope from Babylonia, and thence to Alexandria. Most scholars however have tried to solve the problem by distinguishing between the introduction of the god's statue at the end of the fourth century B.C. and the "creation" of a new cult, most likely in the reign of Ptolemy II. It seems clear that there were at least two, perhaps several, quite different accounts which have become indissolubly fused, so that there can be no final clarity. (...) It is surely more plausible to think that various syncretistic pressures, both native-Egyptian and Graeco-Egyptian, put their stamp on the new god, who, perhaps originally conceived already by Alexander, was then read through the prism of various other deities that seemed to possess analogous features. Though he was marginal among Alexander's gods, Sarapis became important once Egypt came to be ruled by a Macedonian
} 
that the reception of the goddess in Greece was reinforced by the permeability of its polytheistic system to the inclusion of foreign gods and by its tendency towards syncretic assimilation. In addition, the Greek and Egyptian religious systems, in spite of being different, intersected at certain points, allowing for similar empathetic responses and comparisons ${ }^{7}$. What stands out in Isis is the movement of this syncretism: linked to divinities like Demeter, Aphrodite, Artemis, Persephone as well as to Io and forces like Tyche and Providence, the goddess does not fulfil the role of assimilated divinity, but rather of assimilating divinity, thus reinforcing her own autonomy and acquiring a character which would become increasingly multifunctional. As such, contact with the Greek culture did not only amplify the various attributes which the goddess possessed in the Egyptian world, it also made it possible for her to acquire new characteristics and purposes, encompassing different aspects of human life. This polyvalence connected, as it is, to an iconographic attempt to make her more Hellenistic $^{8}$, which in a broad sense translated into a loss of the Egyptian rigidity and an increase of her anthropomorphic figure, due to the stylization of the theriomorphic elements that defined her, are the primary explanations for her success:

The Hellenistic style of Isis in Greece is completely Greek. The goddess was transformed in such an artistic way that she lost any Egyptian character. The fundamental innovation in the Hellenistic iconography of Isis consists in the metamorphosis of the hieratic stiffness of an Egyptianising Isis into a very human beauty. This transformation of the goddess Isis becomes Greek with her anthropomorphic form (Vandebeek 1946: 146) and with elements of a theriomorphic stylised crown of cow horns, crescent or sun-disc ${ }^{9}$.

In the 2nd century, a period of Greco-Oriental influence, the Romans came into contact with the Egyptian cult via its Hellenistic form. Material aspects, such as trade, the growing presence of Eastern slaves in Rome, the army and immigration, as well as the proximity to Sicily (a centre of trade where the cult was already established) and the existence of a community of Romans living in Delos, who could equally have imported the cult ${ }^{10}$, stimulated the expansion of the cult to the cities of the Roman peninsula ${ }^{11}$.

\footnotetext{
king. Quite apart from the other aspects of his identity, the new god obviously needed an appropriate face and bearing, that is, a cult-image. Of course the dates offered by the literary tradition do not fit with such a scenario, but in my view that is not a serious objection, since everyone accepts that the information it provides is unreliable».

${ }^{6}$ Vide NOCK, 1971.

${ }^{7}$ NAOUM, 2008: 18: «Ancient Greek historians such as Plutarch and Diodorus called her the daughter of Cronus and Rhea in terms of Greek mythology and the daughter of Geb and Nut in terms of the Egyptian (...)».

${ }^{8}$ On the iconographic evolution of Isis and, especially, on the iconography of the goddess in the Roman world, vide ARROYO DE LA FUENTE, 2002: 207-232.

${ }^{9}$ NAOUM, 2008: 19.

${ }^{10}$ About these aspects, vide HEYBOB, 1975: 10-11.

${ }^{11}$ According to Heybob, its oldest reference dates back to 105 B.C., in Puteoli. Vide discussion on the initial expansion of the
} 
On the relationship of the cult with the Roman political system, it is worth mentioning the most significant points, seen by scholars, that show that these relations were troubled $^{12}$, in spite of the great tolerance with which the Alexandrian cults were received in the $V r b s^{13}$, especially during the transition from Republic to Empire. This tension was partly a result of the changing political relations between Rome and Egypt. On the other hand, the need to stimulate the political adherence of the lower classes that adopted the cult led the Second Triunvirate to build a temple to Isis and Sarapis in Rome in the year 43 B.C. As Heybob observes, it was a decision that implicitly addressed - as far as Octavian was concerned - not only an appeal to the popular classes, but also a kind of symbolic call for Cleopatra's help against Cesar's assassins ${ }^{14}$.

This dual intention, steered by the necessity of internal support and the maintenance of external alliances, underwent some changes during Augustus' reign due to the influence of new factors and political realities. As such, the movement that, up until that period, had allowed for the desired effects to coincide, both in accordance with the existing realities in the Vrbs and externally, in the relationship with Egypt, had now changed due to the moral policies of Augustus ${ }^{15}$ on the one hand, and, on the other hand, the conflict which set him against Mark Antony. From an internal point of view, the need to renew moral habits,

cult in HEYBOB, 1975: 10-17; and specifically on the matter of Puteoli, in 12-13. Heybob also observes that the cult expanded rapidly in Campania, which is evidence of the markedly urban characteristics of the cult of Isis. Since they first found a home in port cities, or cities that benefited from the fact that they lay on trade routes, which were, each in their own way, more open to the reception of foreign divinities, «It is evident, then, that the Egyptian gods definitely followed the negotiatores». In HEYBOB, 1975: 14 .

${ }^{12}$ HEYBOB, 1975: 18, observes that this tolerance did not, however, diminish the political control of individuals in religious associations, since these associations frequently turned out to be receptacles for subversive ideas, above all among the less privileged classes - a circumstance which must have been must have been behind the abolition, in Rome, of collegiate associations, not to mention the persecutions of the cult, which are documented during the 50s and 40s B.C.

${ }^{13}$ Heybob observes that this tolerance did not, however, diminish the political control over individuals in religious associations, since these associations frequently turned out to be receptacles for subversive ideas, especially among the less privileged classes - which was probably the main cause for the abolition of collegiate associations in Rome, not to mention the persecutions to the cult documented during the 50s and 40s B.C. (HEYBOB, 1975: 18).

14 Vide HEYOB, 1975: 19.

15 Vide HEYBOB, 1975: 24-25 on Augustus' conciliation between the most important political necessities and popular anxieties, which also fed imperial policy and brought a counterbalanced approach between the prohibition of the cult within the limits of the pomerium and the construction and restoration of temples outside it; also on the expulsion en masse of Jews and Egyptians under Tiberius in $19 \mathrm{CE}$, which, in terms of literary explanations, can be as a consequence of the scandal of Paulina's seduction with the help of the priests in the temple of Isis, which led to the crucifixion of the latter and the forced exile of thousands of worshippers, a story whose contours reflect the literary tradition of sexual immorality associated with women members of the cult apparent in Catullus, Juvenal, Josephus, among others; also on the fortune of the cult during the reign of Caligula, the emperor who, in literature, is most associated with Isis (a relationship that, according to TAKÁCS, 1995: 90-91, is explained by the presence of a classroom devoted to Isis in the palace, the prince's adoption of Egyptian customs and clothing, a policy of permissiveness toward Egyptian cults, the construction of a temple to Isis in the Campus Martius and the insertion of the festival that commemorated the death and resurrection of Osiris into the Roman Calendar, a date declared sacra publica populi romani). 
whose principal element was the promulgation of legislation of a moralizing nature (e.g. the Lex Iulia de maritandis ordinibus and the Lex Iulia de adulteries coercendis), fomented a religious reform aimed at promoting Latin religious institutions, which meant, in its turn, the strengthening of the emperor's position. Preference was given to the cults of

Venus Genetrix, Divus Julius, Mars Ultor sentaron las bases de la divinización del emperador, inspirada en las ideas tradicionales del genius y el numen. Por un lado, Augusto enfatizaba la divinidad de su padre adoptivo y, por otro, destacaba la genealogía divina de los Julios, que entroncaban con Venus y Marte, asociando la tradición griega de Eneas y la latina de Rómulo. El templo de Marte fue también recuerdo de las glorias militares y Apolo, a quien Augusto atribuía la victoria de Actium, se consolidó como propiciador de esas victorias militares ${ }^{16}$.

On the other hand, from the perspective of external relations, hostility toward the Egyptian cults cannot be disassociated from the new alliance between Cleopatra and Antony, a character about whom Rome would witness the development of a new iconography, one that associated him with Dionysus or Osiris ${ }^{17}$. If the politico-historical context thoroughly justifies the animosity that began to form and develop in the capital toward the Egyptian alliance, the analysis of coeval literature makes it quite clear that this animosity is related to the exploitation of idiosyncratic fears and of essential ideas associated with the very notion of Romanness and to the opposition between civilization and barbarism. Cleopatra and Mark Antony's victory would be more than just a military victory; it would represent a defeat of an advanced model of civilization, ordered and just, in favour of a widespread implementation of a barbaric and irrational state of civilization. In this sense, it is not surprising to find in literature a recurring association, for example, between Egyptian religion and theriomorphism. The Ekphrasis of Aeneas' shield brings together different elements of a civilizational narrative ideologically organized around the topos of order against disorder ${ }^{18}$, and represents at its very centre the battle between Actium and the rival factions. On one side there is Augustus accompanied by the Senate, the Penates and Agrippa, and protected by Neptune, Venus, Minerva and Apollo; on the other side stand Antony and Cleopatra followed by an army of barbarians and protected by "omni genumque deum monstra et latrator Anubis» (8.698) ${ }^{19}$.

The second time in Roman history in which the political relationship between the state and the Egyptian cults stands out as a merger of their respective interests corre-

\footnotetext{
${ }^{16}$ ARROYO DE LA FUENTE, 2002: 208.

${ }^{17}$ HEYBOB, 1975: 20-21.

18 TEIXEIRA, 2007: 220-22.

${ }^{19}$ Even more explicit, Augustus' speech to his troops, reproduced in Cassius Dio, 50.24-28. As HEYBOB observes (1975: 2021), these works certainly reflect the increasing hostility Augustus felt towards the Egyptian cults.
} 
sponds to the period of the Flavians ${ }^{20}$. This new interest toward Egyptian cults reflects their political development as a way to consolidate power through the divinization of living emperors, thus paving the way for an autocratic political system. The Ptolemaic Dynasty and its osmotic, politico-religious configuration served as the model for this new concept. In this way, the appropriation of Egyptian elements - more than a manifestation of religious interest - served a political purpose: the «assumption by the emperors of titles commonly given to the eastern divinities was directly connected with attempts to unite themselves with deities in order to gradually reach the goal of a living divine monarch $»^{21}$.

The Antonines ${ }^{22}$ also established a relationship with the cult based on protection. Indeed, Egyptian cults seem to have escaped Hadrian's supposedly hostile policies towards foreign cults in general. The subsequent emperors - with the exception of Commodus' presumed active participation in Alexandrian rituals - did not show much interest in cults, although the image of Isis had remained in Rome's coinage ${ }^{23}$. This situation changed completely during the reign of Caracalla, when the interdiction against the celebration of rites inside the pomerium was finally abolished. But also here the renewed interest in the cults of Isis and Sarapis resulted in certain changes in an attempt to establish a model of theocratic power, something which is very evident in the iconography that appears in one of the coins of the emperor, in which «Caracalla, portrayed as Sarapis, is cosmocrator, having power over heaven and earth $»^{24}$. From this moment on, Isis was iconographically preserved in the coinage and had followers until the 4th century, when the destruction of the Serapeum, in Alexandria, extinguished the spiritual centre of the cult and hastened its decline. In 394, the consul Nicomachus Flavianus celebrated the last official festival of the Magna Mater and Isis, although Rutilius Claudius Namatianus would speak of a festival celebrated in Falerii, in $416^{25}$.

If, from a political point of view, the successive positions taken towards the cult and its members reveal a connection between the "establishment» and the religious subsystem, it is interesting to see that to a certain degree this relationship mimics similar conjectures regarding the relationship between the political powers and the religion of the state. If traditional religion provided feudal control ${ }^{26}$, the difficult implementation of the cult of Isis in Rome proves that foreign cults were also appropriated in a way that would favour the communicative and relational dialectic between the state and the necessity for its ruling

\footnotetext{
${ }^{20}$ HЕYBOB, 1975: 26.

${ }^{21}$ HEYBOB, 1975: 26. Vide WITT, 1997: esp. 98-138, on Trajan and Hadrian.

${ }^{22}$ HЕYBOB, 1975: 30.

${ }^{23}$ НЕYBOB, 1975: 30.

${ }^{24}$ Vide WITT, 1997: esp. 98-138, on Trajan and Hadrian.

${ }^{25}$ Information gathered in HЕYBOB, 1975: 35, based on Carmen in paganos, 98-99 (note 208) and Rut. Num., De red. Suo, 1.371-376.

${ }^{26}$ Vide CIAFRARDONE (2010), on Cicero's De diuinatione.
} 
class to affirm itself politically. This is more a consequence than a cause of the cult's expansion, since the stance of the rulers towards the cult followed the dynamics of an empire and its social structure, which were characterized by the weighty presence of foreigners and slaves in Rome and by the important role played by growing commerce and by the symbolical practices developed by the new bourgeoisie. Not to mention how economic and spiritual crises tended to make the Eastern gods more attractive, because they differed very much from the institutional and austere character of the official religion.

Thus, it may be said that the success of the cult is based on a number of factors that arise on a propitious melting pot of cultural and political elements. Among these factors highlights the fact that the Isiac cult has been formed as a model of organized religion which combined, in a close and cohesive way, religiosity and religious institution.

Regarding the first aspect - that of religiosity, the universal, or universalizing, character that the goddess acquired, was fundamental. The presentation that the goddess makes of herself in Apuleius' Asinus aureus, in 11.5, is a good example of this:

Behold, Lucius, moved by your prayers I have come, I the mother of the universe, mistress of all the elements, and first offspring of the ages; mightiest of deities, queen of the dead, and foremost of heavenly beings; my one person manifests the aspect of all gods and goddesses. With my nod I rule the starry heights of heaven, the health-giving breezes of the sea, and the plaintive silences of the underworld. My divinity is one, worshipped by all the world under different forms, with various rites, and by manifold names. In one place the Phrygians, first-born of men, call me Pessinuntine Mother of the Gods, in another the autochthonous people of Attica call me Cecropian Minerva, in another the sea-washed Cyprians call me Paphian Venus; to the arrow-bearing Cretans I am Dictynna Diana, to the trilingual Sicilians Ortygian Proserpina, to the ancient people of Eleusis Attic Ceres; some call me Juno, some Bellona, others Hecate, and still others Rhamnusia; the people of the two Ethiopias, who are lighted by the first rays of the Sun-God as he rises every day, and the Egyptians, who are strong in ancient lore, worship me with rites that are truly mine and call me by my real name, which is Queen Isis. (... $)^{27}$

If this presentation constitutes, in ideological terms, an affirmation of her multifunctionality and power, then the way she is described $(11.3-4)^{28}$ also «stimulates ideological

\footnotetext{
${ }^{27}$ Latin edition and English translation by HANSON, 1989: 298-301.

${ }^{28}$ AA, 11. 3-4: (...) First of all her hair, thick, long, and lightly curled, flowed softly down, loosely spread over her divine neck and shoulders. The top of her head was encircled by an intricate crown into which were woven all kinds of flowers. At its midpoint, above her forehead, a flat round disc like a mirror - or rather a symbol for the moon-glistened with white light. To right and left the crown was bounded by coils of rearing snakes, and adorned above with outstretched ears of wheat. Her robe, woven of sheer linen, was of many colours, here shining with white brilliance, there yellow with saffron bloom, there flaming with rosy redness; and what most especially confounded my sight was a deep black cloak gleaming with dark sheen, which was wrapped about her, running under her right arm up to her left shoulder, with part of its border let down in a form of a knot; it hung in complicated
} 
elements that give this power meaning: the natural elements that make up her clothing are flowers and fruits, which show the divine consonance with a fertile and harmonious natural world; the light, which symbolizes the essence of the divinity, is conveyed through the speculum, the tunica multicolor and the palla nigerrima (....) and lends an idea of harmony and serenity, enemies of chaos and of violence ${ }^{29}$. In all of this shapes Isis is the divinity of order and harmony: she is the one who eliminates the chaos, violence and insecurity with which humanity is confronted. Closely related to this notion is another principle, that the Asinus aureus associates with Isis and that, from this point of view, is not only central to this particular Roman novel, but also to the meaning of the goddess' nature - the principle of justice. Lucius' odyssey makes it quite clear that beyond Isis' ordered world the human being can only be guaranteed one thing: an absence of justice. This is most frequently the result of contingencies and chance, both of which favour the disconnect between guilt and punishment (the stories about adultery, for example), or due to a failure of the judicial contract in human society (as the emphasis given to deceit in the tribune episodes narrated in the novel shows); and, in addition, beyond the ordered world of Isis, the essence of justice is itself perverted, a corruption introduced and maintained by the patronage of traditional divinities, incapable of either exercising justice, or promoting it, as the episodes of Paris' judgment and the Story of Amor and Psyche demonstrate.

The only guaranty of justice is Isis. Likewise, the only guarantee of salvation rests in the goddess. Inspired by Isis ${ }^{30}$, one of her high priests explains to Lucius that his fall was impeded neither by birth, nor by dignitas, or through doctrina, all of which turn out to be insignificant in the presence of latrones, ferae, seruitium, asperrima itinera and metus mortis. If the high priest's words are particularly directed towards Lucius and principally to the story of his life, they also refer to the broader ideology of the fall and the idea that the elements of earthly nature (birth, dignity, culture) are of little importance when it comes to orienting individuals in general. In this sense, the possibility of salvation becomes universal,

pleats, beautifully undulating with knotted tassels at its lower edge. Along the embroidered border and over the surface of the cloak glittering stars were scattered, and their centre the full moon exhaled fiery flames. Wherever streamed the hem of that wondrous robe, a garland of flowers and fruits of every kind was attached to it with an inseparable bond. Latin edition and English translation by HANSON, 1989: 294-297.

${ }^{29}$ TEIXEIRA, 2000: 134.

${ }^{30} \mathrm{AA}, 11.15$ : You have endured many different toils and been driven by Fortune's great tempests and mighty stormwinds; but finally, Lucius, you have reached the harbour of Peace and the altar of Mercy. Not your birth, nor even your position, nor even your fine education has been of any help whatever to you; but on the slippery path of headstrong youth you plunged into slavish pleasures and reaped the perverse reward of your ill-starred curiosity. Nevertheless the blindness of Fortune, while torturing you with the worst of perils, has brought you in its random wickedness to this holy state of happiness. Let her begone now! Let her rage in all her fury and hunt some other object for her cruelty, for hostile chance has no opportunity against those whose lives the majesty of our goddess has emancipated into her own servitude. Robbers, wild animals, slavery, the twists and turns of the harshest journeys that end where they begin, the daily fear of death - what benefit were all these to wicked Fortune? But now you have been taken under the protection of a Fortune who can see, and who with the brilliance of her own light illumines all the other gods as well. (...) Latin edition and English translation by HANSON, 1989: 318-321. 
by showing, through Lucius' experience, that salvation is not realized neither in the psychological principle of repent, nor in the philosophical principle of learning, but only in the theological principle of magna proudentia Isidis. It becomes clear that this salvation, as it is based only on a voluntary act of submission to the goddess and her cult, is accessible to the human race in general. This is a Providence that, contrary to what happened with traditional divinities, is a regulating entity, offers justice and security and which, in theological terms, presents the only guarantee of man's deliverance.

Therefore, it is the combination of spiritual factors, which combine a high degree of mysticism with answers and guarantees for the anxieties and problems of life, which explains the growing popularity and success of this cult. These answers and guarantees were certainly no less negligible due to the fact that they extended to post mortem life, an idea which, in the case of Isis, was developed from the divine narrative itself, in which the goddess insists that her stay on earth is only transitory, preserving her true reign for the afterlife. In addition, there are also institutional factors ${ }^{31}$, among which is the promotion of the congregating and integrative character of the cult. In fact, if the cult was initially confined to the least favoured classes of the population (slaves, freemen and foreigners), historical evidence suggests that, with time, the cult attracted a vast and varied group of individuals of different races and all levels of society.

The openness of the cult is evident in Apuleius' description, in Book XI of the $A A$, of the Navigium Isidis, the most important festival dedicated to the goddess, held at the beginning of the seafaring epoch, on the fifth day of March.

The procession described therein tells of the presence of a great number of symbolic objects, which show the powerful process of the goddess' acculturation into the GrecoRoman sphere (of which the Navigium Isidis itself is an example) and which testify to the multifunctionality of the goddess (emblems of justice, lanterns, symbol of light, amphorae), and of others which testify to her connection with Egypt (Anubis; a cow «symbol of fecundity and image of the mother goddess of all things» (11.11-2); palm fronds; the sistrum; linen clothes). However, it is the makeup of the group that accompanies the procession that best shows the popularity of the cult. In addition to the successive waves of initiates in the divine mysteries, women and men of all ranks and ages, it also includes a jocular group of masked characters that, allegorically, represent human professions, showing

\footnotetext{
${ }^{31}$ ALVAR, 2008: 62, explains the success of Sarapis' cult in a similar way: «Despite his absence from the mythological cycle, then, and despite recognition of his recent origin, the cult of Serapis succeeded thanks at least partly to institutional backing. On the one hand, the men who put him together as a divinity of abundance well knew how to appeal to the needs in view of which he was created. On the other, it was the prestige of the Ptolemies (often indeed their territorial conquests), and of Isis, that enabled his cult to spread through the eastern Mediterranean. Serapis' polyvalence helped meet the politico-religious uncertainties of the Hellenistic period: a god of everything, omnipresent, director of the cosmos, lord of production and reproduction, bulwark of monarchy, succour of the little man - and to all that he added personal command of the world beyond the grave. This was the kind of symbolic capital that a god now needed if he were to triumph».
} 
that, in the unifying framework of Isiac cult, under the patronage of a divinity of many names and multiple forms, a diversity of human types and social categories have found hospitality, from the gladiator to the magistrate, from the soldier to the hunter and the fisherman, from the woman to the street philosopher. Particularly significant is the presence of the woman and the street philosopher, since they convey sociological premises which make it possible to reach certain conclusions about the expansion of the cult to areas of the broader society that were traditionally not involved in it. As Gionotti observes, in this way, these two symbolical characters seem to ensure the universality of the Isiac cult: women, due to the primary role of the feminine element in the Isiac cult, are granted citizenship, traditionally given only to men; and the philosopher no longer labelled an exceptional character, joins the procession, which gathers within it all social categories ${ }^{32}$.

As far as women are concerned, if the Egyptian goddess did not serve as a specifically feminine role, the Hellenistic Isis emphasized this attribute due to her connection with maternity. Nevertheless, although distinct from her Egyptian origins, in which the goddess seems to have been a cosmic divinity with a clear funerary function ritualized around the death of Osiris, Isis' most particular characteristic, which seemed to be essential for the cult's expansion in the Roman world, is her association to Osiris and her role as family member evoked in the Isis-Osiris-Horus paradigm. In the words of Amparo Arroyo, Isis had appeared as a Mother-goddess and Rome would come to know her as such. In addition to the representations of her as Panthea and other syncretic representations, the «iconografía de la Isis lactans, que gozó de una enorme difusión por todo el Imperio e adquiriu inclusivamente um carácter netamente occidental, uma vez que a par das estátuas marcadas por elementos orientalizantes que lembram a origem egípcia, se encontram outras que a convirtieron en una matrona romana dedicada a amamantar a Harpócrates» ${ }^{33}$. This feminine character, which naturally attracted the understanding of women, became for them a model of inspiration, galvanized by the possibility of an effective participation in the cult and of access to the religious hierarchy.

By including the philosopher among the cult's worshippers, Apuleius' Asinus aureus offers something to think about as to the adhesion of individuals from a full range of culturally and socially elevated strata.

The problem of religion, particularly the debate over the nature of divinities, as it was linked to the problem of death, was always a controversial subject among Greek schools of philosophy, and was later argued over methodically in Rome at least from the period of Cic$\mathrm{ero}^{34}$. Influenced by Stoicism, the philosophical-religious thinking considered the existence of a divinity - the fatum - superior to all others, with a regulating power over men and

\footnotetext{
${ }^{32}$ GIANOTTI, 1986: 91.

${ }^{33}$ ARROYO DE LA FUENTE, 2002: 218.

${ }^{34}$ Cf. MACKENDRICK, 1989.
} 
gods. This was a divinity that accommodated a monotheistic spirit, or, as in Isis' case, monotheistic tendencies.

Likewise, poetic, philosophic and religious traditions of Platonic, Orphic and Pythagorean influence, conveyed ideas of post mortem salvation and condemnation. These ideas are revealed in literary contexts, such as in the description of the underworld in the Aeneid, in which «the notion of the afterlife as a release from toil which we find in the last part of Book 6 of the Aeneid probably springs from popular belief and folklore crystallized and organized by Orphic mystery religions and Pythagorean philosophy; many Orphic ideas were developed by Plato, and many were assimilated in Stoicism» ${ }^{35}$.

Thus, the reason why these religions were so successful and experienced such growing acceptance is not some exogenous phenomenon which seeped into the empire and suddenly replaced the traditional religion. Ruptures were already apparent in the classic paradigm, some of them part of a long philosophic-religious tradition that mostly found expression in certain erudite circles; while others, more recent and more likely to be found among the popular classes, were a result of the empire's growing crisis and of the traditional religion's failure to provide answers.

This intellectual tendency was appropriated and adapted to the beliefs of the Isiac cult. Apuleius' Asinus aureus shows evidence of this. The connection of Isiac elements present in the first ten books and the more explicit Isiac message in the last book effectively make the story of Lucius - who, in Book III, inadvertently turns himself into an ass because of his obsession with the magic ars and is saved by the divine intervention of Isis - into a kind of Isiac morality tale, which is not strictly confined to a religious perspective. This perspective, which cements the notion of an ontological tale of fall and resurrection, evolves through a complex game of philosophical entities and notions: Fatum, Necessitas, Providentia and Fortuna $^{36}$. These concepts, which display a neo-Platonic origin coupled with Stoic variants, lend themselves to the formation of a religious plain as it emerges out of a highly evolved

\footnotetext{
${ }^{35}$ WILLIAMS, 1990: 192.

${ }^{36}$ An interpretive definition of these entities based on philosophical works attributed to Apuleius could be seen in FRY, 1984: 137-170. The concept of Fortuna (139-141) «apparaît 21 fois dans les opuscula. Si l'on excepte les 11 occurrences où elle ne revêt que son sens pécuniaire, ses 10 autres apparitions la présentent chaque fois comme une divinité mal définie, au comportement instable, le plus souvent génératrice de maux. (...); Quant à Prouidentia, elle apparaît 16 fois (dont 7 dans Plat. 1 , 12). A 4 reprises elle ne signifie que «prévoyance humaine». Dans les autres cas, elle prend le sens de «ordonnatrice du monde»». Il est en outre précisé dans mund. 24 que l'Être qui dirige l'univers (mundi rector) (...) se sert de sa Providence pour en assurer la création matérielle et en préserver la cohérence. (...). Fatum apparaît à 15 reprises (...). À chaque fois, ce mot exprime l'idée d'une loi préétablie dont les termes échappent à l'entendement humain. (...) La pensée extrêmement éclectique de l'auteur du De mundo semble n'avoir laissé aucune part au libre arbitre ou à la contingence, pour ne prôner qu'un strict déterminisme. (...). La Necessitas est l'instrument utilisé par la divinité pour contraindre l'homme à accomplir son destin.(...) La Providence guide ce que l'on accomplit de son plein gré tandis que ce qui nous est imposé l'est par la Necessitas. L'une et l'autre ne sont, par conséquent, que deux aspects opposés mais complémentaires d'une seule et même réalité: la volonté du Fatum».
} 
philosophical perspective: «Étant maîtresse de la destinée humaine, elle a été assimilée à la Fortune (...). Si la conduite de l'homme est conforme à sa volonté, elle est Providence; dans cas contraire, elle peut se faire contraignante, voire répressive. (...) l'unique possibilité d'échapper aux décrets du destin est de se plier totalement aux exigences de la déesse (...) $)^{37}$.

The fact that the cult did not exhaust itself in one single kind of universality, aimed simply at achieving a general adhesion, is equally significant. In effect, although it was open to all, after joining the cult each individual was encouraged to adopt an intimate rapport with the goddess. This rapport was made possible through the ritual of initiation, which, according to Plutarch, would represent death and resurrection, after which the follower would expand his/her relationship with the divinity. Putting aside the numerous interpretations of the actual Mysteries and other meanings of the ritual, and once again calling upon the work of Apuleius, Lucius' initiation, first into the Mysteries of Isis and then those of Osiris, proves that this kind of direct contact with the divinity is a real possibility - a possibility that, once accomplished, brings an inrenumarable beneficium to the initiate, which is then translated not only into Happiness and the spiritual benefits brought about through a life of complete religiosity, but which also extend to the material aspects of life. This last fact can be inferred from the promising professional career as a lawyer which Osiris predicts for Lucius, as well as the affirmation that he would be granted admission into the School of Pastophors.

In this sense, despite several conflicting theories whether regarding historical or chronological aspects which have to do with the goddess' appearance in the Greco-Roman context, or in terms of syncretic elements and certain aspects related to the religion's institutional realities, it would not be too bold to say that Isis and her cult became one of the most popular foreign cults in the Roman context. Its success was determined not so much by the political sympathy which gradually it would come to claim, but more by the fact that its message was so well suited to the Roman zeitgeist and by its hability to mould itself to the needs of the individuals envolved in the cult thus increasing the direct connection between the individual, the goddess and the temple. This is the message that ultimately Lucius leaves at the end of Asinus Aureus, summing up his life of devotion to the goddess in a single word: Happiness.

${ }^{37}$ FRY, 1984: 145. 